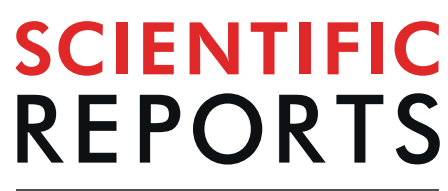

natureresearch

\title{
OPEN Calcium carbonate alters the functional response of coastal sediments to eutrophication- induced acidification
}

Received: 31 March 2019

Accepted: 5 August 2019

Published online: 19 August 2019

\author{
Tarn P. Drylie ${ }^{1}{ }^{1}$, Hazel R. Needham ${ }^{1}$, Andrew M. Lohrer ${ }^{2}$, Adam Hartland ${ }^{1}$ \& \\ Conrad A. Pilditch ${ }^{1}$
}

Coastal ocean acidification research is dominated by laboratory-based studies that cannot necessarily predict real-world ecosystem response given its complexity. We enriched coastal sediments with increasing quantities of organic matter in the field to identify the effects of eutrophication-induced acidification on benthic structure and function, and assess whether biogenic calcium carbonate $\left(\mathrm{CaCO}_{3}\right)$ would alter the response. Along the eutrophication gradient we observed declines in macrofauna biodiversity and impaired benthic net primary productivity and sediment nutrient cycling. $\mathrm{CaCO}_{3}$ addition did not alter the macrofauna community response, but significantly dampened negative effects on function (e.g. net autotrophy occurred at higher levels of organic matter enrichment in $+\mathrm{CaCO}_{3}$ treatments than $\left.-\mathrm{CaCO}_{3}\left(1400 \mathrm{vs} 950 \mathrm{~g} \mathrm{dw} \mathrm{m}^{-2}\right)\right)$. By identifying the links between eutrophication, sediment biogeochemistry and benthic ecosystem structure and function in situ, our study represents a crucial step forward in understanding the ecological effects of coastal acidification and the role of biogenic $\mathrm{CaCO}_{3}$ in moderating responses.

Acidification of seawater via the increasing absorption of atmospheric $\mathrm{CO}_{2}$ (ocean acidification; $\mathrm{OA}$ ) is a key contemporary issue for the marine environment ${ }^{1}$. However, eutrophication-induced acidification ${ }^{2}$ has received comparatively little attention, despite affecting vast portions of the world's coastal zones ${ }^{3}$. Eutrophication is defined as an increase in the rate of supply of organic carbon to an ecosystem and occurs in coastal waters primarily via the anthropogenic input of excess nutrients ${ }^{4}$. Excess nutrients promote short-lived algal blooms which, upon collapsing, are deposited to the benthos ${ }^{5}$ where microbially-driven aerobic respiration of organic matter releases $\mathrm{CO}_{2}$ in approximate equivalence to $\mathrm{O}_{2}$ consumption ${ }^{6}$, causing localised acidification ${ }^{7}$. In highly productive estuarine environments, eutrophication-induced acidification adds variation to background fluctuations in $\mathrm{pH}$ driven by changing rates of respiration and photosynthesis ${ }^{8,9}$ and watershed effects ${ }^{10}$, and occurs against a backdrop of global OA that is set to reduce seawater $\mathrm{pH} 0.3-0.4$ units by $2100^{11}$. The co-occurrence of these acidification pathways means coastal environments may experience decreases in seawater $\mathrm{pH}$ far exceeding those predicted from OA alone ${ }^{12-14}$. Additionally, biogeochemical changes associated with aerobic (i.e., $\mathrm{O}_{2}$ depletion) and anaerobic (i.e., dissimilatory $\mathrm{N}$ and $\mathrm{S}$ reduction) pathways of benthic organic matter degradation mean that acidification rarely acts in isolation, but is rather a single component in a multi-stressor setting also comprising hypoxia and increased concentrations of toxic solutes ${ }^{15,16}$.

Coastal benthic macrofauna communities exhibit predictable responses to organic matter enrichment, such as reduced abundance and diversity at high levels of loading ${ }^{17}$. These responses are usually attributed to the onset of hypoxia $^{3}$, however empirical evidence suggests some organisms respond more strongly to fluctuations in $\mathrm{pH}$ than $\mathrm{O}_{2}$ (e.g. juvenile clams $)^{18}$. Whilst it is generally accepted that calcifying organisms will fare poorly under acidification due to calcium carbonate $\left(\mathrm{CaCO}_{3}\right)$ under-saturation and increased likelihood of dissolution ${ }^{19-21}$, the consequences for non-calcifying organisms are less certain and vary interspecifically ${ }^{22}$. Understanding the response of benthic communities to decreasing $\mathrm{pH}$ is critical, as numerous ecosystem services (e.g. food production and nutrient cycling) are underpinned by functions (e.g. primary production and organic matter mineralisation)

${ }^{1}$ School of Science, University of Waikato, Private Bag 3240, Hamilton, New Zealand. ${ }^{2}$ National Institute of Water and Atmospheric Research (NIWA), PO Box 11115, Hamilton, New Zealand. Correspondence and requests for materials should be addressed to T.P.D. (email: tdrylie5@gmail.com) 
that are strongly influenced by resident macrofauna ${ }^{23,24}$. Evidence from laboratory experiments suggests that processes such as denitrification may be disrupted by decreases in seawater $\mathrm{pH}$, owing to a breakdown in the facilitative interactions between macrofauna and denitrifying bacteria ${ }^{25,26}$. Naturally occurring gradients of acidification have been utilised to investigate the effects on benthic communities in the field, for example by monitoring communities with increasing distance from shallow volcanic $\mathrm{CO}_{2}$ vents ${ }^{27-29}$. Whilst these studies have provided insights into potential changes in community structure, including decreases in the abundance of calcareous organisms, and even evolutionary adaptations, there are frequently additional environmental variables that co-vary along the gradient (such as temperature and toxic trace elements) making it difficult to attribute the responses to acidification alone ${ }^{30}$.

The difficulty in conducting controlled acidification experiments in situ has meant benthic OA research has tended towards laboratory-based studies often using simplified biological communities or individual species. Of the 324 studies published by 2014 on marine organisms' responses to reduced coastal $\mathrm{pH}$, three quarters were conducted in the laboratory ${ }^{31}$. Whilst laboratory-based studies provide a controlled mechanistic understanding of acidification effects, they cannot predict in situ ecological responses given the complexity of natural ecosystems. For example, the ability for mobile organisms to disperse from impacted sediments ${ }^{32}$ is inhibited when entire experimental units (e.g. cores or mesocosms) are acidified, but this is a crucially important behavioural trait providing resilience to benthic communities when considered at landscape or ecosystem scales ${ }^{33,34}$. Recent OA field studies have also highlighted how functional redundancy in benthic communities may provide resilience against acidification which would otherwise be masked in low diversity laboratory studies. Baggini et al. ${ }^{35}$ documented a switch in the main grazer of macroalgae from sea urchins to fishes along a gradient of increasing $\mathrm{CO}_{2}$ concentration, preventing a phase shift from an ecosystem dominated by encrusting algae to macroalgae. Numerous laboratory studies have previously identified positive responses of marine autotrophs to increased $\mathrm{CO}_{2}\left(\mathrm{see}^{36}\right)$, but this may not be observed in situ if species replacement maintains grazing pressure.

Furthermore, laboratory experiments frequently neglect the multi-stressor nature of benthic acidification (the usual mechanism for reducing seawater $\mathrm{pH}$ is via the bubbling of $\mathrm{CO}_{2}$ gas ${ }^{37,38}$, shifting water column $\mathrm{pH}$ only), and the natural buffering capacity of the coastal environment may be overlooked or poorly replicated in artificial settings. To make empirical studies more relevant to the real-world, Hewitt et al. ${ }^{39}$ advocate conducting field experiments across environmental gradients to address scaling issues between the understanding gleaned from simplified small-scale laboratory experiments and the response of diverse large-scale ecosystems ${ }^{40,41}$.

The complex biogeochemistry of the coastal zone is likely to affect ecological responses to acidification. Coastal ocean sediments contain approximately $50 \%$ of oceanic $\mathrm{CaCO}_{3}$ deposits, originating in temperate regions mostly from bivalve shells and bryozoan skeletons ${ }^{42}$. $\mathrm{CaCO}_{3}$ minerals dissolve in response to increased acidity from $\mathrm{CO}_{2}$ hydrolysis, according to equations (i) and (ii).

$$
\begin{gathered}
\mathrm{CO}_{2(\mathrm{~g})}+2 \mathrm{H}_{2} \mathrm{O}_{(\mathrm{aq})}<->\mathrm{HCO}_{3(\mathrm{aq})}{ }^{-}+\mathrm{H}_{3} \mathrm{O}^{+}{ }_{(\mathrm{aq})} \\
\mathrm{CaCO}_{3(\mathrm{~s})}+\mathrm{H}_{3} \mathrm{O}_{(\mathrm{aq})}^{+}<->\mathrm{HCO}_{3(\mathrm{aq})}{ }^{-}+\mathrm{H}_{2} \mathrm{O}_{(\mathrm{aq})}+\mathrm{Ca}^{2+}{ }_{(\mathrm{aq})}
\end{gathered}
$$

When $\mathrm{CO}_{2}$ hydrolysis and $\mathrm{CaCO}_{3}$ dissolution are coupled in this way, there is no net change in hydronium ion $\left(\mathrm{H}_{3} \mathrm{O}^{+}\right)$concentration and thus no change in $\mathrm{pH}\left(\mathrm{pH}=-\log \left[\mathrm{H}_{3} \mathrm{O}^{+}\right]\right)$, although buffering capacity, i.e. the ability to neutralise $\mathrm{H}_{3} \mathrm{O}^{+}$, increases according to the increase in $\mathrm{HCO}_{3}^{-43}$. The porewaters of $\mathrm{CaCO}_{3}$-rich coastal sediments may therefore possess high buffering capacities ${ }^{44,45}$ which reduce the potential for significant fluctuations in $\mathrm{pH} . \mathrm{CaCO}_{3}$ has even been suggested as a tool to prevent the negative effects of localised benthic acidification ${ }^{46}$. Whilst Green et al.$^{47}$ observed a three-fold increase in bivalve recruitment in cores buffered with crushed shell hash, Greiner et al. ${ }^{48}$ observed no such effect in similarly buffered plots, despite significant increases in porewater $\mathrm{pH}$. To date, the only field study investigating the link between benthic acidification, $\mathrm{CaCO}_{3}$ buffering and ecosystem function was inconclusive due to heterogeneity in the environment ${ }^{49}$. It is necessary to clarify the nature of these linkages as intensifying coastal acidification may remove the key species that consolidate $\mathrm{CaCO}_{3}$ into sediments ${ }^{50}$ and lead to dissolution of existing $\mathrm{CaCO}_{3}$ deposits ${ }^{51}$, such that any resilience provided by $\mathrm{CaCO}_{3}$ buffering to ecosystem functioning will be lost.

In this study, the ability of biogenic $\mathrm{CaCO}_{3}$ to maintain intertidal benthic ecosystem structure and function along a gradient of eutrophication-induced acidification was investigated in situ. Organic matter enrichment treatments (0-2250 $\mathrm{g} \mathrm{dw} \mathrm{m}^{-2}$, increasing in $250 \mathrm{~g}$ increments) formed the eutrophication gradient, and enriched plots $\left(1.44 \mathrm{~m}^{2}\right)$ were allocated one of two $\mathrm{CaCO}_{3}$ treatments (with or without the addition of $2000 \mathrm{~g} \mathrm{~m}^{-2}$, i.e. $+\mathrm{CaCO}_{3}$ or $-\mathrm{CaCO}_{3}$ treatments). After $70 \mathrm{~d}$ of enrichment we assessed treatment effects on sediment properties, macrofauna community structure and key ecosystem functions (e.g. net primary production and nutrient processing), which were derived from solute fluxes across the sediment-water boundary measured in light and dark benthic incubation chambers. The presumed mechanism by which $\mathrm{CaCO}_{3}$ would increase resilience was through reducing the range of $\mathrm{pH}$ variability via buffering of $\mathrm{CO}_{2}$ (Eqs 1 and 2). As such, it was hypothesised that sediments with abundant $\mathrm{CaCO}_{3}$ would experience less extreme fluctuations in $\mathrm{pH}$ than those without when mineralising excess organic matter to $\mathrm{CO}_{2}$. If fluctuating $\mathrm{pH}$ was the primary eutrophication-induced stressor, the macrofauna community was expected to be less affected by organic matter enrichment when there was excess $\mathrm{CaCO}_{3}$, helping to maintain ecosystem function. Conversely, a lack of a positive effect of $\mathrm{CaCO}_{3}$ could indicate that additional eutrophication-induced stressors (hypoxia, $\mathrm{H}_{2} \mathrm{~S}$ toxicity) were more important regulators.

To test our predictions, one-way PERMANOVA (using the PERMANOVA + package of Primer V7) were performed with $\mathrm{CaCO}_{3}$ treatment considered a fixed factor and organic matter treatment a continuous co-variable. This approach allowed assessment of the interactive effects of organic matter and $\mathrm{CaCO}_{3}$ treatments on response variables. Some ecosystem functions were variable yet significantly correlated with organic matter treatment, 


\begin{tabular}{|l|l|l|l|l|l|}
\hline Treatment & $\begin{array}{l}\text { Median grain size } \\
(\boldsymbol{\mu} \mathbf{m})\end{array}$ & $\begin{array}{l}\text { Mud content } \\
(\%)\end{array}$ & $\begin{array}{l}\text { Organic content } \\
(\%)\end{array}$ & $\begin{array}{l}\text { Chlorophyll } \boldsymbol{a} \\
\left(\boldsymbol{\mu} \mathbf{g ~ g}^{-1} \mathbf{d w}\right)\end{array}$ & $\begin{array}{l}\text { Phaeopigment } \\
\left(\boldsymbol{\mu} \mathbf{g ~ g}^{-1} \mathbf{d w}\right)\end{array}$ \\
\hline Ambient $(\mathrm{n}=3)$ & $189(187-190)$ & $2.6(1.7-4.7)$ & $1.7(1.6-1.9)$ & $10.3(10.1-14.2)$ & $5.1(4.4-5.6)$ \\
\hline $\mathrm{PC}(\mathrm{n}=4)$ & $191(185-195)$ & $4.5(2.3-5.7)$ & $2.1(1.9-2.2)$ & $10.2(8.2-14.5)$ & $3.6(3.4-5.7)$ \\
\hline$+\mathrm{CaCO}_{3}(-\mathrm{OM})(\mathrm{n}=4)$ & $193(190-197)$ & $3.1(1.3-4.5)$ & $1.8(1.7-1.9)$ & $11.5(9.5-12.5)$ & $3.6(2.9-4.8)$ \\
\hline$+\mathrm{CaCO}_{3}(+\mathrm{OM})(\mathrm{n}=14)$ & $192(177-199)$ & $2.6(1.1-6.1)$ & $1.9(1.7-3.0)$ & $11.8(8.9-20.3)$ & $6.0(4.3-22.7)$ \\
\hline$-\mathrm{CaCO}_{3}(+\mathrm{OM})(\mathrm{n}=14)$ & $191(182-198)$ & $2.8(1.3-3.5)$ & $2.0(1.7-2.4)$ & $11.6(6.6-15.2)$ & $5.7(2.2-27.1)$ \\
\hline
\end{tabular}

Table 1. Surface sediment $(0-2 \mathrm{~cm})$ characteristics in ambient, procedural control (PC) and treatment plots. Medians (and ranges) are given.

therefore multiple regression (using distance-based linear models (DistLM) in Primer V7) was also performed to determine environmental drivers (e.g. sediment properties, macrofauna community structure) of this variability.

\section{Results}

Seventy days after manipulation, surface sediment characteristics $(0-2 \mathrm{~cm})$ were similar between plots (Table 1$)$ and any effects of the disturbance caused by treatment establishment had subsided (see Supplementary Information for ambient and control treatment comparisons). Only phaeopigments, a product of chlorophyll degradation, showed a relatively large range $\left(2-27 \mu \mathrm{g} \mathrm{g}^{-1} \mathrm{dw}\right)$ driven by high values in organically enriched plots. At $2-5 \mathrm{~cm}$ sediment depth (organic matter and $\mathrm{CaCO}_{3}$ were added at a depth of $5 \mathrm{~cm}$ ) a significant elevation of $\mathrm{CaCO}_{3}$ content in $+\mathrm{CaCO}_{3}$ treatments $(1.4 \%)$ versus $-\mathrm{CaCO}_{3}$ treatments $(0.5 \%)(\mathrm{F}(1,33)=12.81, \mathrm{p}=0.001$; Fig. 1a) was achieved. There was no significant interactive effect between $\mathrm{CaCO}_{3}$ and organic matter treatments on organic content $(\mathrm{OC})$ or porewater $\mathrm{pH}$, but there was a significant effect of organic matter treatment (Table 2). We observed a linear increase in $\mathrm{OC}$ along the organic matter treatment gradient $\left(\mathrm{r}^{2}=0.44, \mathrm{p}<0.001 ;\right.$ Fig. 1b) with mean OC doubling from $2 \%$ in $0 \mathrm{~g} \mathrm{dw} \mathrm{m}^{-2}$ plots to $4 \%$ in $2250 \mathrm{~g} \mathrm{dw} \mathrm{m}^{-2}$ plots, and a linear decrease in porewater $\mathrm{pH}$ from 7.3 to $6.6\left(\mathrm{r}^{2}=0.47, \mathrm{p}<0.001\right.$; Fig. 1c). Both $\mathrm{OC}$ and porewater $\mathrm{pH}$ exhibited high variability, particularly at the highest levels of organic matter treatment.

Macrofauna abundance data were averaged from two cores per plot, and total abundance and total number of taxa were determined per core $\left(133 \mathrm{~cm}^{2}\right)$. These community indices were only affected by organic matter treatment; $\mathrm{CaCO}_{3}$ treatment and its interaction with organic matter were both insignificant (Table 2). Mean total abundance decreased by $72 \%\left(r^{2}=0.74, p<0.001\right.$; Fig. $\left.2 a\right)$ and total species by $31 \%\left(r^{2}=0.52, p<0.001\right.$; Fig. $\left.2 b\right)$ along the organic matter treatment gradient.

Fluxes of dissolved solutes (oxygen (DO), ammonium $\left(\mathrm{NH}_{4}^{+}\right)$, nitrite $\left(\mathrm{NO}_{2}^{-}\right)$and nitrate $\left(\mathrm{NO}_{3}^{-}\right)$) across the sediment-water interface were used to derive indicators of key ecosystem functions pertaining to primary productivity (PP), community metabolism and nutrient processing: light chamber DO flux was equivalent to net PP (NPP) and dark chamber DO flux corresponded to sediment oxygen consumption (SOC; a proxy for community metabolism). Fluxes of nitrogenous compounds indicated rates of nutrient cycling, with $\mathrm{NH}_{4}{ }^{+}$being the first product of organic matter mineralisation which may be further oxidised into $\mathrm{NO}_{2}{ }^{-}$and $\mathrm{NO}_{3}{ }^{-}$(combined and represented as $\mathrm{NO}_{\mathrm{x}}$ ). Treatment effects were not consistent across ecosystem functions; $\mathrm{NPP}$ and $\mathrm{NH}_{4}{ }^{+}$ flux exhibited significant relationships with organic matter treatment, whereas SOC and $\mathrm{NO}_{\mathrm{x}} \operatorname{did} \operatorname{not}($ Table 2). Chambers at low levels of enrichment were initially autotrophic $(\mathrm{PP}>\mathrm{SOC})$ during light incubations and became heterotrophic (SOC $>$ PP) at higher levels of organic matter treatment (Fig. 3a). $\mathrm{CaCO}_{3}$ treatment significantly altered the response of NPP to organic matter enrichment (Table 2), with $+\mathrm{CaCO}_{3}$ plots exhibiting net autotrophy to higher levels of organic matter treatment than $-\mathrm{CaCO}_{3}$ plots $\left(\sim 1400\right.$ versus $\left.\sim 950 \mathrm{~g} \mathrm{dw} \mathrm{m}^{-2}\right)$. NPP decreased significantly with increasing organic matter treatment in $-\mathrm{CaCO}_{3}$ plots $\left(\mathrm{r}^{2}=0.77, \mathrm{p}<0.001\right)$, whereas the loss in productivity in $+\mathrm{CaCO}_{3}$ plots was less steep, more variable and was only marginally correlated with organic matter treatment $\left(\mathrm{r}^{2}=0.24, \mathrm{p}=0.05\right)$. SOC showed no relationship with organic matter or $\mathrm{CaCO}_{3}$ treatments (Fig. 3b, Table 2) with high variability across the range of organic matter treatments.

Under light conditions natural log-transformed $\mathrm{NH}_{4}{ }^{+}$flux $\left(\mathrm{NH}_{4}{ }^{+}\right.$light $)$showed a significant response to organic matter treatment, but not $\mathrm{CaCO}_{3}$ or its interaction with organic matter treatment (Table 2). As organic matter enrichment increased, the rate of $\mathrm{NH}_{4}{ }^{+}$light efflux from sediments increased exponentially $\left(\mathrm{r}^{2}=0.65, \mathrm{p}=<0.001\right.$; Fig. 3c), such that the rate of $\mathrm{NH}_{4}{ }^{+}$light efflux was more than 500 times greater in 2250 versus $0 \mathrm{~g} \mathrm{dw} \mathrm{m}^{-2}$ treatments. In light chambers, $\mathrm{NO}_{\mathrm{x}}\left(\mathrm{NO}_{\mathrm{x}}\right.$ light $)$ showed a marginally significant response to $\mathrm{CaCO}_{3}$ addition (but not organic matter treatment; Table 2$)$, with a slight decrease in net uptake $\left(\sim 15 \mu \mathrm{mol} \mathrm{m}{ }^{-2} \mathrm{~h}^{-1}\right)$ in $+\mathrm{CaCO}_{3}$ treatments (Fig. 3e). Under dark conditions (i.e. in the absence of microphytobenthos (MPB) uptake), there was a significant relationship between organic matter treatment and natural log-transformed $\mathrm{NH}_{4}{ }^{+}\left(\mathrm{NH}_{4}{ }^{+}\right.$dark $)$efflux which changed with $\mathrm{CaCO}_{3}$ treatment, as indicated by the significant interaction term (Table 2). In $-\mathrm{CaCO}_{3}$ treatments, efflux of $\mathrm{NH}_{4}{ }^{+}$dark increased exponentially as organic matter treatment increased $\left(\mathrm{r}^{2}=0.35, \mathrm{p}=0.01\right.$; Fig. 3d), however this relationship was absent in $+\mathrm{CaCO}_{3}$ treatments and efflux rates were generally reduced. There was far greater variability in nutrient cycling measurements obtained under dark versus light conditions.

When constructing multiple regression models, marginal tests first identified significant $(\mathrm{p}(\mathrm{perm})<0.1)$ predictors of response variables when considered alone, and full models then determined the best combination of predictor variables after accounting for the variance attributed to organic matter treatment (organic matter treatment was always fitted first). In marginal tests, variability in ecosystem functions was correlated with several variables including organic matter treatment, sediment characteristics and macrofauna community indices (Table 3). For functions that exhibited a significant interaction between organic matter and $\mathrm{CaCO}_{3}$ treatments (NPP and $\mathrm{NH}_{4}{ }^{+}$dark $)$, the $-\mathrm{CaCO}_{3}$ treatment had a greater number of significant predictors that individually explained 


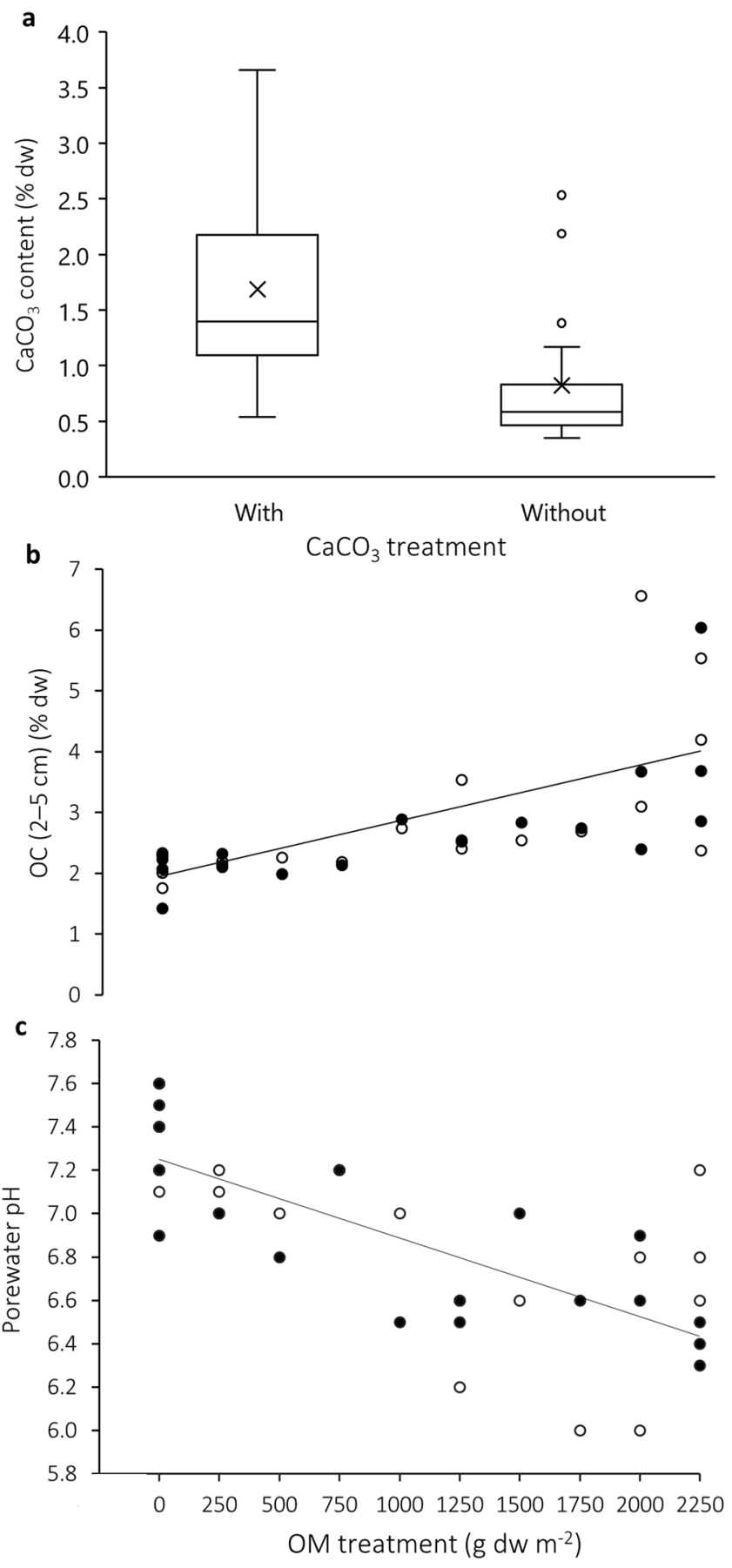

Figure 1. Effects of treatments $\left(\mathrm{CaCO}_{3}\right.$ and organic matter $(\mathrm{OM})$ addition $)$ on sediment $(\mathbf{a}) \mathrm{CaCO}_{3}$ content ( $\mathrm{t}$-test, $\mathrm{p}=0.001)(\mathbf{b})$ organic content $(\mathrm{OC})\left(\mathrm{r}^{2}=0.44, \mathrm{p}<0.001\right)$ and $(\mathbf{c})$ porewater $\mathrm{pH}\left(\mathrm{r}^{2}=0.47, \mathrm{p}<0.001\right)$ $70 \mathrm{~d}$ after manipulation. Closed symbols represent $-\mathrm{CaCO}_{3}$ treatments and open symbols represent $+\mathrm{CaCO}_{3}$ treatments. Regression lines are fitted to the pooled data set (see Table 2). Boxplot whiskers indicate the nonoutlier range, with circles marking outliers. Box limits represent 25th and 75th percentiles, lines intersecting boxes are median values and crosses within boxes are means.

more of the variation than the $+\mathrm{CaCO}_{3}$ treatment. When organic matter treatment was fitted first, it was the only predictor included in backwards elimination linear regression models of NPP for both $\mathrm{CaCO}_{3}$ treatments, but the amount of variance explained decreased from $76 \%$ in $-\mathrm{CaCO}_{3}$ treatments to $21 \%$ in $+\mathrm{CaCO}_{3}$ treatments. Although macrofauna total abundance and porewater $\mathrm{pH}$ explained large amounts of variance in $\mathrm{NPP}\left(-\mathrm{CaCO}_{3}\right.$ treatments) in marginal tests, both variables were highly correlated with organic matter treatment $(r>0.8)$ and were excluded from the model. The variables included in the full model of $\mathrm{NH}_{4}{ }^{+}$dark flux differed depending on $\mathrm{CaCO}_{3}$ treatment. A combination of organic matter treatment and sediment characteristics $\left(\mathrm{CaCO}_{3}\right.$ content and phaeopigments) together explained $68 \%$ of the variance in $-\mathrm{CaCO}_{3}$ treatments, whereas only $17 \%$ of the variance 


\begin{tabular}{|c|c|c|c|c|}
\hline \multirow{3}{*}{\multicolumn{2}{|c|}{\begin{tabular}{|l|} 
\\
Sediment characteristics \\
\end{tabular}}} & Source & Pseudo-F & $\begin{array}{l}\mathbf{p} \\
\text { (perm) }\end{array}$ \\
\hline & & & & \\
\hline & & OM & 26.1 & 0.0001 \\
\hline \multirow{2}{*}{\multicolumn{2}{|c|}{ OC $(2-5 \mathrm{~cm})$}} & $\mathrm{CaCO}_{3}$ & 0.61 & 0.45 \\
\hline & & $\mathrm{OM} \times \mathrm{CaCO}_{3}$ & 0.26 & 0.62 \\
\hline \multirow{3}{*}{\multicolumn{2}{|c|}{ Porewater $\mathrm{pH}$}} & OM & 28.9 & 0.0001 \\
\hline & & $\mathrm{CaCO}_{3}$ & 0.03 & 0.87 \\
\hline & & $\mathrm{OM} \times \mathrm{CaCO}_{3}$ & 0.003 & 0.96 \\
\hline \multicolumn{5}{|c|}{ Macrofauna } \\
\hline \multirow{3}{*}{\multicolumn{2}{|c|}{ Total abundance }} & $\mathrm{OM}$ & 100 & 0.0001 \\
\hline & & $\mathrm{CaCO}_{3}$ & 0.49 & 0.49 \\
\hline & & $\mathrm{OM} \times \mathrm{CaCO}_{3}$ & 1.30 & 0.27 \\
\hline \multirow{3}{*}{\multicolumn{2}{|c|}{ Total species }} & $\mathrm{OM}$ & 38.6 & 0.0001 \\
\hline & & $\mathrm{CaCO}_{3}$ & 1.15 & 0.29 \\
\hline & & $\mathrm{OM} \times \mathrm{CaCO}_{3}$ & 1.98 & 0.17 \\
\hline \multicolumn{5}{|c|}{ Ecosystem functions } \\
\hline \multirow{3}{*}{\multicolumn{2}{|c|}{ NPP }} & $\mathrm{OM}$ & 39.4 & 0.0001 \\
\hline & & $\mathrm{CaCO}_{3}$ & 0.26 & 0.66 \\
\hline & & $\mathrm{OM} \times \mathrm{CaCO}_{3}$ & 8.91 & 0.007 \\
\hline \multirow{3}{*}{\multicolumn{2}{|c|}{ SOC }} & $\mathrm{OM}$ & 0.52 & 0.48 \\
\hline & & $\mathrm{CaCO}_{3}$ & 0.17 & 0.68 \\
\hline & & $\mathrm{OM} \times \mathrm{CaCO}_{3}$ & 1.56 & 0.23 \\
\hline \multirow{6}{*}{$\ln \mathrm{NH}_{4}^{+}$} & \multirow{3}{*}{ Light } & $\mathrm{OM}$ & 62.8 & 0.0001 \\
\hline & & $\mathrm{CaCO}_{3}$ & 0.001 & 0.98 \\
\hline & & $\mathrm{OM} \times \mathrm{CaCO}_{3}$ & 1.69 & 0.21 \\
\hline & \multirow{3}{*}{ Dark } & OM & 0.61 & 0.44 \\
\hline & & $\mathrm{CaCO}_{3}$ & 0.89 & 0.35 \\
\hline & & $\mathrm{OM} \times \mathrm{CaCO}_{3}$ & 11.4 & 0.002 \\
\hline \multirow{6}{*}{$\mathrm{NO}_{\mathrm{x}}$} & \multirow{3}{*}{ Light } & OM & 1.07 & 0.31 \\
\hline & & $\mathrm{CaCO}_{3}$ & 3.12 & 0.08 \\
\hline & & $\mathrm{OM} \times \mathrm{CaCO}_{3}$ & 0.04 & 0.84 \\
\hline & \multirow{3}{*}{ Dark } & OM & 0.06 & 0.80 \\
\hline & & $\mathrm{CaCO}_{3}$ & 0.30 & 0.59 \\
\hline & & $\mathrm{OM} \times \mathrm{CaCO}_{3}$ & 0.98 & 0.33 \\
\hline
\end{tabular}

Table 2. Results of PERMANOVA testing the direct and interactive effects of organic matter (OM, continuous covariable) and $\mathrm{CaCO}_{3}$ (fixed factor) treatments on sediment characteristics, macrofauna community and ecosystem functions. Bolded values indicate significant $(\mathrm{p}($ perm $)<0.05)$ and italicised values indicate marginally significant $(\alpha<0.1)$ effects. $\mathrm{OC}=$ organic content, NPP $=$ net primary production, $\mathrm{SOC}=$ sediment oxygen consumption and $\ln \mathrm{NH}_{4}{ }^{+}=$natural log-transformed ammonium.

was explained in the full model for $+\mathrm{CaCO}_{3}$ treatments by organic matter treatment. In marginal tests total species explained more of the variation in $+\mathrm{CaCO}_{3}$ treatments than organic matter treatment, but was excluded from the full model. For $\mathrm{NH}_{4}{ }^{+}$light flux, despite numerous variables being identified as significant predictors when considered alone, only two were included in the full model; organic matter treatment contributed most of the total variance explained (66 of 71\%), with the remainder attributed to chlorophyll $a(\mathrm{Chl} a)$, an indicator of MPB abundance.

\section{Discussion}

Natural fluctuations in $\mathrm{pH}$ may be extreme in the benthos of productive estuarine environments ${ }^{8}$, however coastal eutrophication and global OA are set to intensify acidification across varying scales of magnitude, space and time such that benthic ecosystem functions may be compromised. For the first time an in situ manipulation of porewater $\mathrm{pH}$ and investigation of the ability of $\mathrm{CaCO}_{3}$ to prevent negative change has shown that $\mathrm{CaCO}_{3}$ deposits may increase the functional resilience of benthic ecosystems to localised eutrophication-induced acidification.

The decline of benthic biodiversity with increasing inputs of organic matter is well-documented and usually attributed to the inducement of hypoxic conditions ${ }^{17,52}$, however the potential for co-occurring porewater acidification to drive these declines has been comparatively under-studied. The highest organic matter treatment resulted in a porewater $\mathrm{pH}$ of 6.6, and the loss of one third of macrofauna species and almost three quarters of total individuals. No increase in porewater $\mathrm{pH}$ could be detected in $+\mathrm{CaCO}_{3}$ treatments, nor any difference in the relationship between macrofauna community indices and organic matter treatment. This suggests that $\mathrm{CaCO}_{3}$ did not buffer porewater $\mathrm{pH}$ sufficiently to decrease the physiological stress of the organisms, or that other 

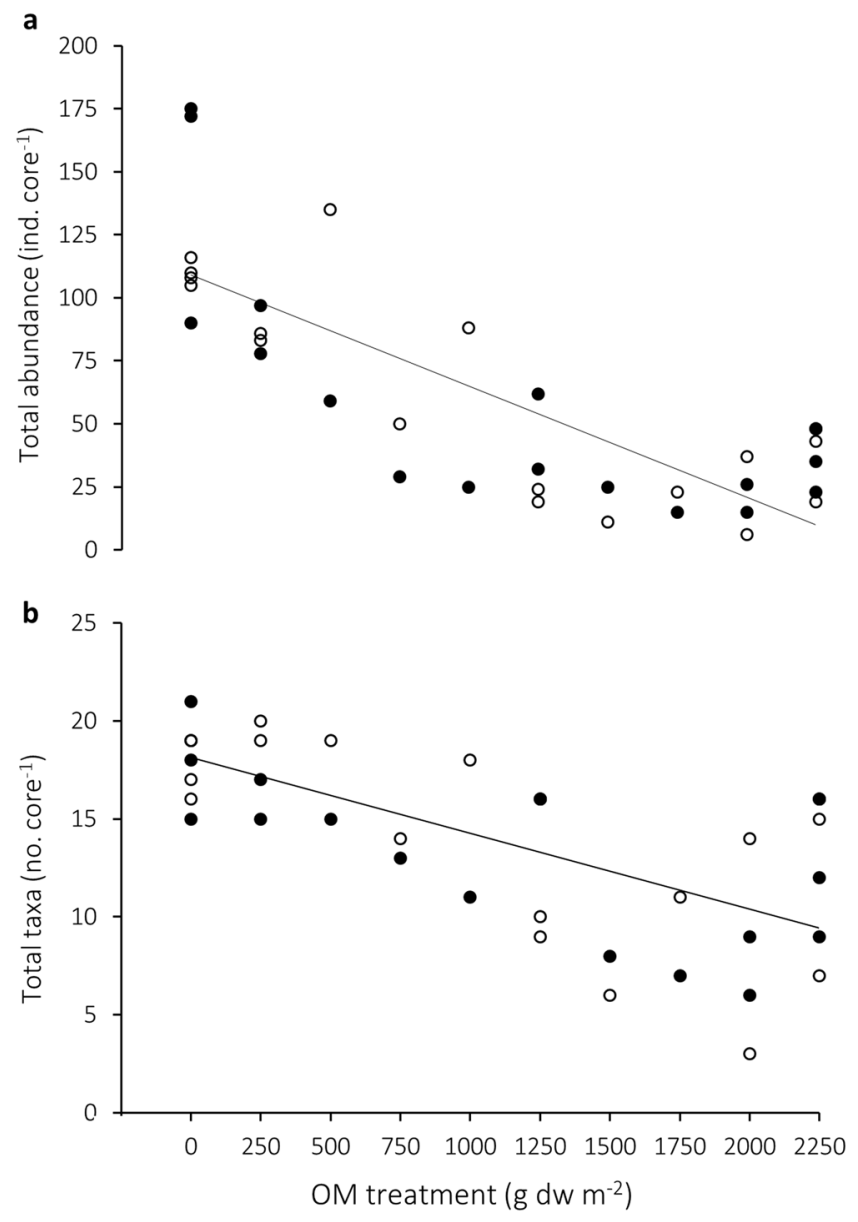

Figure 2. Macrofauna community response to organic matter $(\mathrm{OM})$ treatment: (a) total abundance $\left(\mathrm{r}^{2}=0.74\right.$, $\mathrm{p}<0.001)$ and $(\mathbf{b})$ total taxa $\left(\mathrm{r}^{2}=0.52, \mathrm{p}<0.001\right)$. Closed symbols represent $-\mathrm{CaCO}_{3}$ treatments and open symbols represent $+\mathrm{CaCO}_{3}$ treatments, and regression lines are fitted to the pooled data set (see Table 2).

consequences of organic matter degradation such as hypoxia or increased $\left[\mathrm{H}_{2} \mathrm{~S}\right]$ were more important in driving the macrofaunal response. The latter seems most likely, given $\mathrm{CaCO}_{3}$ dissolution under open-system conditions would serve to maintain $\mathrm{pH}$ within a given range, rather than drive it higher than typical pore water values ${ }^{43}$.

These biodiversity losses were associated with a predictable decrease in function, given biodiversity-ecosystem functioning relationships are frequently density-dependent ${ }^{53}$ and/or underpinned by key species ${ }^{54,55}$. NPP decreased significantly along the organic matter treatment gradient whilst $\mathrm{NH}_{4}{ }^{+}$light efflux increased, indicating a decrease in the utilisation of nutrients by the MPB community. Chl $a$ biomass, a proxy for MPB abundance, showed no relationship with organic matter treatment and therefore cannot explain trends in NPP. It has been hypothesised that increased $\mathrm{pCO}_{2(\mathrm{aq})}$ would result in increased productivity of photoautotrophs, and although most research has focussed on seagrasses and macroalgae ${ }^{36,56,57}$, increases in the PP of MPB have been observed in the laboratory following exposure to $\mathrm{CO}_{2}$-acidified seawater ${ }^{37,57}$. The unfavourable sediment conditions (low $\mathrm{pH}$, low $\left[\mathrm{O}_{2}\right]$ ) created here may have stressed the MPB community beyond being able to take advantage of excess $\mathrm{CO}_{2}$. The decrease in abundance of macrofauna, whose activities are known to stimulate MPB PP ${ }^{58}$, may also have played a role. However, $\mathrm{CaCO}_{3}$ addition increased the resilience of NPP to these conditions. Significant increases in $\mathrm{pH}$, total alkalinity (TA) and saturation states have been measured previously as a result of biogenic $\mathrm{CaCO}_{3}$ dissolution ${ }^{44,47,51}$, so the coarse methods used to measure $\mathrm{pH}$ changes here (pH field probe with $\pm 0.2 \mathrm{pH}$ units accuracy) may have masked finer scale alterations to porewater biogeochemistry which benefitted the MPB community. Importantly, $\mathrm{CaCO}_{3}$ addition had the effect of maintaining autotrophy of the benthic ecosystem to a considerably higher level of organic matter treatment, and this effect was strong enough to be detected amid the complexity of the field.

The response of light and dark nutrient cycling to organic matter treatment (increasing efflux of $\mathrm{NH}_{4}{ }^{+}$and no response of $\mathrm{NO}_{\mathrm{x}}$ ) indicates a limitation or breakdown of microbially-mediated nitrification pathways that oxidise $\mathrm{NH}_{4}{ }^{+}$to $\mathrm{NO}_{2}{ }^{-}$and $\mathrm{NO}_{3}{ }^{-}$. There are several ways that organic matter treatment may have limited nitrification, for example a decrease in bioturbation and bioirrigation activity driven by the decrease in macrofaunal abundance may have reduced the availability of aerobic sediments ${ }^{59}$, which are required by microbial nitrifiers (i.e. ammonia- and nitrite-oxidisers). However, Braeckman et al.$^{60}$ have previously shown that in the short-term $(14 \mathrm{~d})$, decreases in benthic nitrification rates under acidified conditions are mediated predominantly by changes in microbial community activity, rather than macrofaunal facilitation. Inhibition of nitrifiers at low $\mathrm{pH}$ may 

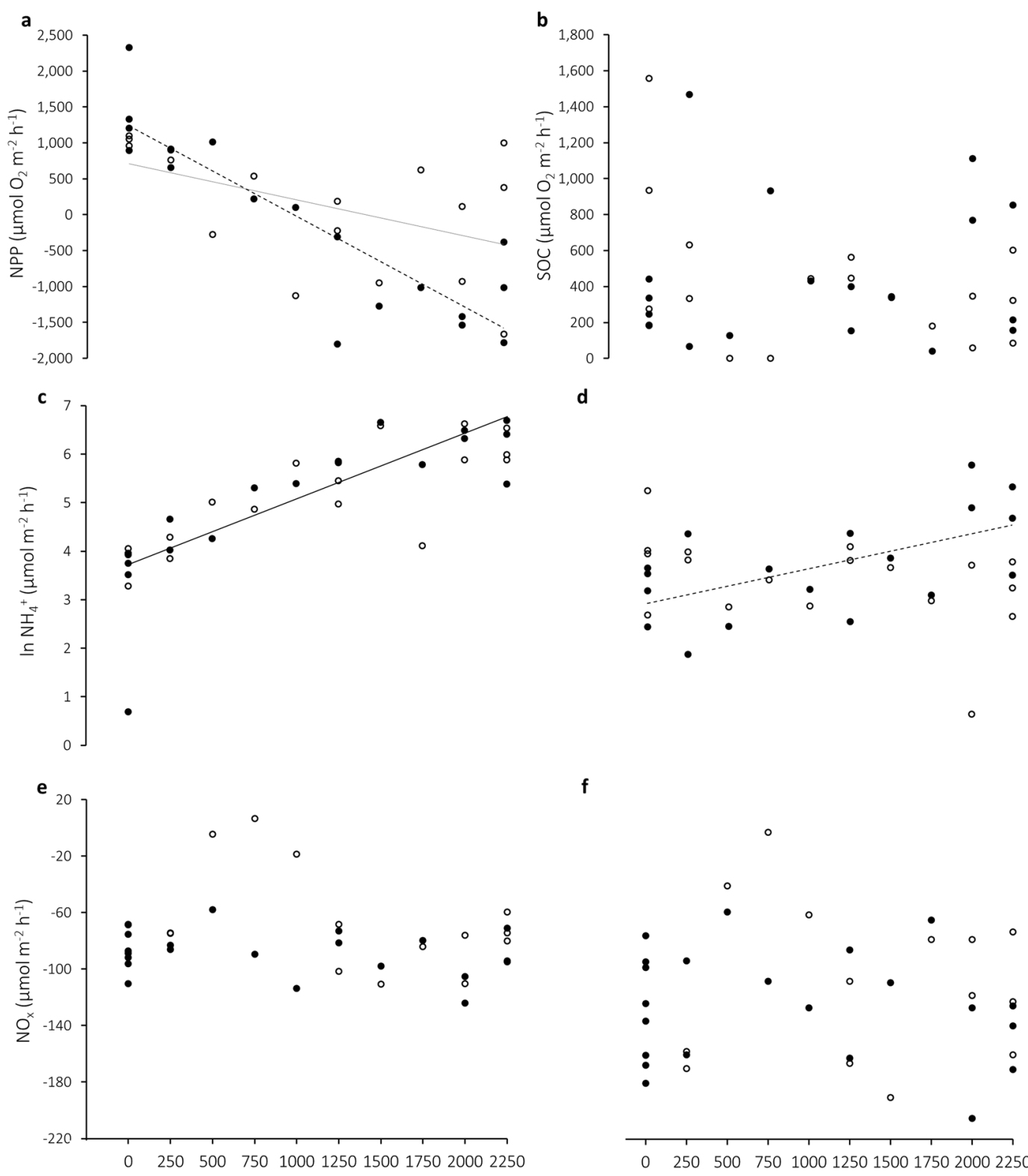

d

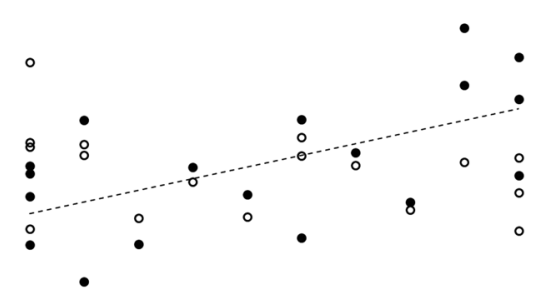

f

OM treatment

Figure 3. Response of ecosystem functions to organic matter (OM) and $\mathrm{CaCO}_{3}$ addition: (a) net primary productivity (NPP); (b) sediment oxygen consumption (SOC); (c) natural log-transformed ammonium $\left(\mathrm{NH}_{4}{ }^{+}\right)$efflux in the light and (d) dark; (e) combined nitrite and nitrate $\left(\mathrm{NO}_{\mathrm{x}}\right)$ uptake in the light and (f) dark. Closed symbols represent $-\mathrm{CaCO}_{3}$ treatments and open symbols represent $+\mathrm{CaCO}_{3}$ treatments. Significant $(\alpha<0.05)$ linear regressions are indicated (see text for test statistics): dashed line $=-\mathrm{CaCO}_{3}$ treatment; solid grey $=+\mathrm{CaCO}_{3}$ treatment; solid black $=$ combined $\mathrm{CaCO}_{3}$ treatments (i.e. no interaction between $\mathrm{OM}$ and $\mathrm{CaCO}_{3}$ treatments; see Table 2).

therefore be a factor, although it is expected that microbes are tolerant to considerable fluctuations in $\mathrm{pH}$ and Kitidis et al.$^{61}$ previously found no significant decrease in nitrification rates at $\mathrm{pH}$ 6.1. Substrate-limitation is perhaps the most likely cause as $\mathrm{NH}_{3}$ is the true substrate for ammonia-oxidisers, yet below $\mathrm{pH} \sim 8.0 \mathrm{NH}_{3}$ is present almost exclusively as $\mathrm{NH}_{4}{ }^{+62,63}$. Alternatively, biogeochemical processes such as dissimilatory $\mathrm{NO}_{\mathrm{x}}$ reduction to $\mathrm{NH}_{4}{ }^{+}$may have increased $\left[\mathrm{NH}_{4}{ }^{+}\right]$, a process which can be quantitatively more important than denitrification in organically-rich sediments $\mathrm{s}^{64,65}$.

$\mathrm{CaCO}_{3}$ addition altered the relationship between nutrient cycling and organic matter treatment (in the dark only), such that there was no trend of increasing $\mathrm{NH}_{4}{ }^{+}$efflux in $+\mathrm{CaCO}_{3}$ treatments. As porewater $\mathrm{O}_{2}$ would have been scarce in dark conditions (absence of photosynthesis) and $\mathrm{CaCO}_{3}$ addition had no effect on the macrofaunal community, it is unlikely that the improvement to sediment conditions that helped maintain nitrification rates was due to increasing availability of aerobic sediments. Similarly, there was no detected increase in $\mathrm{pH}$ with $\mathrm{CaCO}_{3}$ addition, therefore $\mathrm{NH}_{3}$ availability should be equally limiting. It seems most likely, therefore, 


\begin{tabular}{|c|c|c|c|c|c|}
\hline Function & Treatment & Variable & Pseudo-F & Proportion & Total \\
\hline \multirow[t]{12}{*}{ NPP } & $-\mathrm{CaCO}_{3}$ & OM treatment & 60.3 & $0.76 * * *$ & \\
\hline & & Total abundance & 20.8 & $0.52 * * *$ & \\
\hline & & Porewater $\mathrm{pH}$ & 18.0 & $0.49 * * *$ & \\
\hline & & Phaeopigments & 8.63 & 0.31 *** & \\
\hline & & OC $2-5 \mathrm{~cm}$ & 7.38 & $0.28 * * *$ & \\
\hline & & Total species & 7.46 & $0.28^{* *}$ & \\
\hline & & Mud content & 4.74 & $0.2^{* * *}$ & \\
\hline & & & & & $76 \%$ \\
\hline & $+\mathrm{CaCO}_{3}$ & OM treatment & 7.01 & $0.21 * * *$ & \\
\hline & & Total abundance & 10.6 & $0.4^{* * * *}$ & \\
\hline & & Porewater $\mathrm{pH}$ & 3.64 & $0.19^{*}$ & \\
\hline & & & & & $21 \%$ \\
\hline Ln Dark & $-\mathrm{CaCO}_{3}$ & OM treatment & 9.76 & $0.34^{* * * *}$ & \\
\hline \multirow[t]{9}{*}{$\mathrm{NH}_{4}{ }^{+}$flux } & & Phaeopigments & 10.1 & $0.35 * * *$ & \\
\hline & & $\mathrm{CaCO}_{3}$ content & 5.86 & $0.24 * *$ & \\
\hline & & Total abundance & 4.93 & $0.21 * *$ & \\
\hline & & Total species & 3.39 & $0.15^{*}$ & \\
\hline & & & & & $68 \%$ \\
\hline & $+\mathrm{CaCO}_{3}$ & OM treatment & 3.34 & $0.17 *$ & \\
\hline & & Total species & 6.61 & $0.29 * *$ & \\
\hline & & Total abundance & 4.1 & $0.2^{*}$ & \\
\hline & & & & & $17 \%$ \\
\hline Ln Light & & OM treatment & 73.1 & $0.66^{* * * *}$ & \\
\hline \multirow[t]{7}{*}{$\mathrm{NH}_{4}{ }^{+}$flux } & & Total abundance & 51.7 & $0.58 * * *$ & \\
\hline & & Porewater $\mathrm{pH}$ & 18.4 & $0.33^{* * *}$ & \\
\hline & & OC $2-5 \mathrm{~cm}$ & 15.6 & $0.3 * * *$ & \\
\hline & & Total species & 14.4 & $0.28 * * *$ & \\
\hline & & Phaeopigments & 5.19 & $0.12 * *$ & \\
\hline & & Chl $a$ & 4.89 & $0.12 * *$ & \\
\hline & & & & & $71 \%$ \\
\hline
\end{tabular}

Table 3. Results of DistLM determining best combinations of predictor variables (backwards elimination procedure) explaining ecosystem function response to organic matter $(\mathrm{OM})$ treatment. OM treatment was fitted first in all models and $\mathrm{CaCO}_{3}$ treatments are analysed separately where significant interactions between $\mathrm{OM}$ and $\mathrm{CaCO}_{3}$ treatments occur. Proportion gives the amount of variability explained by each variable when considered alone (marginal tests). Variables in bold were included in the best full models and total shows the total variation explained by full models. Level of significance: $* \mathrm{p}<0.1, * * \mathrm{p}<0.05, * * * \mathrm{p}<0.01$.

that subtle changes to porewater biogeochemistry that were not measured played a role in improving conditions for nutrient cycling microbes. In future research it will be important to monitor a larger suite of carbonate chemistry parameters ( $\mathrm{pH}, \mathrm{TA}$, dissolved inorganic carbon (DIC)) to identify the mechanisms underlying these functional responses. However, the aim of this study was to investigate whether laboratory-based theory could be applied in the field, and indeed, $\mathrm{CaCO}_{3}$ addition successfully dampened the negative effects of organic matter enrichment on nutrient cycling. This justifies further investigation of these interactions in situ and has important consequences for the functioning of coastal ecosystems, given the conversion of biologically-available nitrogen to nitrogenous gas provides resilience against further eutrophication ${ }^{66,67}$.

Whilst some ecosystem functions responded strongly to organic matter treatment, SOC showed no relationship with enrichment, OC or porewater $\mathrm{pH}$. Since SOC is the net result of biological (BOD) and chemical oxygen demand (COD) $)^{68}$, it was hypothesised that SOC would increase with organic matter treatment due to an increased BOD of the stimulated microbial community and COD from increasing abundance of reducing substances, as has previously been reported for organically enriched sediments (e.g. ${ }^{69-71}$ ). The lack of a relationship may be explained by a 'compensation' in $\mathrm{O}_{2}$ consumption along the organic matter treatment gradient, whereby the gradual decrease in respiration and $\mathrm{O}_{2}$ consumption facilitated by macrofauna (due to decreasing abundance and stress-induced change in activity levels) was offset by a gradual increase in microbial respiration and COD, such that overall SOC remained constant.

In $-\mathrm{CaCO}_{3}$ treatments combinations of organic matter treatment, sediment characteristics and macrofauna community variables were important predictors of $\mathrm{NPP}$ and $\mathrm{NH}_{4}{ }^{+}$dark flux. In $+\mathrm{CaCO}_{3}$ treatments far fewer variables were significant predictors of function, though macrofauna community indices remained significant and individually explained more variation than organic matter treatment. This implies a strong facilitation of ecosystem function by the macrofauna community even when the geochemical complexities of sediments are enhanced. Organic matter treatment was the only predictor included in several full models (when fitted first), highlighting 
the dominant effect of this stressor on ecosystem function, however there was a substantial decrease in the variance it explained in $+\mathrm{CaCO}_{3}$ treatments compared to $-\mathrm{CaCO}_{3}$. This discrepancy may have been associated with the microbial component of the ecosystem, as it is the microbial community that converts and transforms solutes, though the macrofauna and sediment characteristics are key controllers of solute transport rates and microbial microhabitats ${ }^{72}$. Changes to porewater chemistry may also have driven the responses observed, therefore including a greater number of carbonate chemistry parameters and microbial community indicators in models may result in greater explanation of the functional response.

In this short-term, single-application experiment, $\mathrm{CaCO}_{3}$ effectively reduced the negative effects of organic matter enrichment on ecosystem function. However, over longer timeframes and repeated $\mathrm{CaCO}_{3}$ applications there may be potential effects associated with its addition. The extent of these effects will likely be dependent upon the difference in grain size between the ambient sediment and the added $\mathrm{CaCO}_{3}$, and whether this difference substantially alters grain size distribution. If so, benthic ecosystem functions could be affected as diffusive solute exchange across the sediment-seawater interface is highly dependent upon sediment permeability ${ }^{73}$, and the effects of macrofaunal bioturbation on function change along gradients of sediment grain size ${ }^{74}$. To avoid such impacts $\mathrm{CaCO}_{3}$ should be crushed or ground to match the sediment characteristics of the receiving site prior to addition, whilst keeping in mind that the dissolution rates of $\mathrm{CaCO}_{3}$ will vary as a function of grain size ${ }^{44}$.

\section{Conclusions}

Benthic ecosystem functions respond demonstrably to experimentally elevated organic matter and $\mathrm{CaCO}_{3}$ content in a field setting, despite complex interactions occurring between levels of biological organisation and environmental characteristics that influence function. Porewater acidification resulting from organic matter enrichment has negative effects on primary production and nutrient cycling which are dampened by the addition of biogenic $\mathrm{CaCO}_{3}$, thus increasing the resilience of the ecosystem to this stressor. The lack of a beneficial effect of $\mathrm{CaCO}_{3}$ on macrofauna biodiversity suggests other stressors associated with eutrophication (hypoxia, $\mathrm{H}_{2} \mathrm{~S}$ toxicity) were stronger determinants of community structure than $\mathrm{pH}$. The positive effects of $\mathrm{CaCO}_{3}$ addition may therefore be microbially mediated, and future research should focus on the combined response of macro- and microbiological communities to coastal eutrophication in situ. Developing a mechanistic understanding of how $\mathrm{CaCO}_{3}$ provides resilience to ecosystem function will be crucial, as losses of key $\mathrm{CaCO}_{3}$-producing species are likely under future coastal acidification stressors.

\section{Methods}

The experiment was conducted in the mid-intertidal zone of Tuapiro estuary $\left(37^{\circ} 29.406^{\prime}, 175^{\circ} 57.074^{\prime}\right)$ within Tauranga Harbour, New Zealand. The site experiences a diurnal tidal cycle with inundation periods of $\sim 5 \mathrm{~h}$ and a mean water depth $\sim 1.2 \mathrm{~m}$ upon maximum inundation. Plots were established within a $12 \mathrm{~m} \times 30 \mathrm{~m}\left(360 \mathrm{~m}^{2}\right)$ area of homogeneous fine sand (median grain size $191 \mu \mathrm{m})$ with low mud (silt/clay particles $<63 \mu \mathrm{m})(<5 \%), \mathrm{CaCO}_{3}$ $(<1 \%)$ and organic content (1.6-2.2\% in un-enriched plots) (Table 1$)$.

In austral summer ( $31^{\text {st }}$ January 2017), forty $1.44 \mathrm{~m}^{2}$ plots were established ( $2 \mathrm{~m}$ apart) in a 10 column by 4 row array. Four replicates of each of the following three treatments were randomly allocated: ambient (no treatment), procedural control (PC; sediment disturbed mimicking treatment setup) and plots that received $\mathrm{CaCO}_{3}$ (pure crushed oyster shell, fragments $<5 \mathrm{~mm})$ but no organic matter $\left(+\mathrm{CaCO}_{3}(-\mathrm{OM})\right.$ ). The remaining 28 plots were randomly assigned one of nine organic matter enrichment treatments created using $250-2250 \mathrm{~g} \mathrm{dw} \mathrm{m}^{-2}$ of organic plant-derived slow-release garden fertiliser (treatments increasing in $250 \mathrm{~g}$ increments in a gradient design). Enriched plots were also assigned $\mathrm{a} \mathrm{CaCO}_{3}$ treatment (with or without the addition of $2000 \mathrm{~g} \mathrm{dw} \mathrm{m}^{-2}$ ). Replication was carried out for the lowest $\left(250 \mathrm{~g} \mathrm{~m}^{-2}(\mathrm{n}=3)\right)$, middle $\left(1250 \mathrm{~g} \mathrm{~m}^{-2}(\mathrm{n}=2)\right)$ and highest $(2000$ $(\mathrm{n}=2)$ and $\left.2250 \mathrm{~g} \mathrm{~m}^{-2}(\mathrm{n}=3)\right)$ organic matter treatments. The materials used to create organic matter and $\mathrm{CaCO}_{3}$ treatments were chosen to mimic natural inputs to estuarine systems, whilst slow-release fertiliser ensured sustained organic matter degradation would result in alterations to the biogeochemical properties of the sediment.

Plots were excavated to $5 \mathrm{~cm}$ depth, taking care to minimise disruption to the sediment matrix, before evenly distributing organic matter and $\mathrm{CaCO}_{3}$ (in the $+\mathrm{CaCO}_{3}$ treatments) across plots and replacing sediment. The organic matter enrichment range was chosen to create a gradient in sediment $O C$ that would elicit a response typical of eutrophically-stressed systems (i.e. acidified porewaters and reduced biodiversity), and represents a one-off depositional event such as a macroalgal bloom collapse. Such events are common globally (e.g. ${ }^{75,76}$ ) and in the wider estuary due to seasonal Ulva spp. blooms ${ }^{77}$. The level of $\mathrm{CaCO}_{3}$ enrichment elevated the average ambient content at the study site by $10 \mathrm{x}$, which is representative of the use of $\mathrm{CaCO}_{3}$ as an acidification mitigation tool rather than a natural increase in $\mathrm{CaCO}_{3}$ content. Comparisons of sediment characteristics, macrofaunal community indices and benthic solute fluxes between ambient, procedural and $\mathrm{CaCO}_{3}$ control plots confirmed there was no significant effect associated with the presence of the added $\mathrm{CaCO}_{3}$ or the procedure of adding it to the sediment (see Supplementary Information).

Benthic solute fluxes and sediment properties were measured in situ after nine weeks $\left(3^{\text {rd }}-4^{\text {th }}\right.$ April 2017 , early austral autumn), and macrofauna communities were sampled the following week (11 ${ }^{\text {th }}$ April 2017), allowing time for changes in the sediment biogeochemistry and macrofauna community to occur. Benthic flux incubations were conducted over two days with midday high tides. Fluxes of dissolved solutes across the sediment-water interface were measured under light and dark conditions in each plot, i.e. in the presence and absence of photosynthesis. As rates of photosynthesis vary with light intensity ${ }^{78}$, all light measurements were conducted on day one (and dark measurements on day two) so that chambers experienced the same light regime ${ }^{79}$. One ambient plot was dropped from the analysis due to a chamber malfunction.

The operation of the incubation chambers used for measuring benthic fluxes has previously been described $^{80-82}$. Briefly, plots were divided into quarters and chamber bases (L50 $\times$ W50 $\left.\times \mathrm{H} 15 \mathrm{~cm}\right)$ were positioned in a randomly chosen quarter $\sim 10 \mathrm{~cm}$ from plot edges, and inserted $5 \mathrm{~cm}$ into the sediment. On day 2 (dark 
incubations), chambers were placed diagonally opposite to the day 1 position to minimise disturbance effects. HOBO Pendant temperature and light loggers (Onset) were installed in 16 of the chambers dispersed across the site, with an additional three secured on the seafloor (10 s sampling frequency). Domed Perspex lids were clamped onto bases on the incoming tide, encapsulating $\sim 34 \mathrm{~L}$ of water. Lids were transparent for light incubations, whilst double-layered shade cloth covered lids for dark incubations. Previous measurements using HOBO loggers have recorded zero light inside chambers covered using this method (V. Rullens, unpublished data). Syringe-drawn water samples $(60 \mathrm{~mL})$ were collected in triplicate at the start and end of the $\sim 4$-h incubation. Ambient seawater samples $(n=3)$ were collected as chambers were sealed, and 3 light and dark pairs of $1 \mathrm{~L}$ bottles were filled and secured at the seafloor for the duration of the incubations; sampling the bottles at the end of incubations allowed determination of the contribution of water column processes to solute fluxes. Water column processes accounted for $<7 \%$ of benthic solute fluxes in both light and dark conditions and were therefore ignored. Seawater DO was measured immediately using an optical probe (PreSens FIBOX 3 LCD trace v7); a two-point calibration was performed prior to measurements in a $\mathrm{Na}_{2} \mathrm{SO}_{4} \mathrm{O}_{2}$-free (0\%) solution and air-saturated water (100\%) following the manufacturer's instructions. Samples were then filtered through $0.8 \mu \mathrm{m}$ glass fibre filters (Whatman GF/F) and stored frozen, in the dark prior to analysis of dissolved nutrient concentrations.

Weather conditions varied substantially between days of benthic flux measurements; day 1 was sunny with little wind wave activity whereas day 2 was cloudy with intermittent rain and some wind wave activity. Although the cloudier conditions experienced on day 2 were irrelevant in terms of incident sunlight (day of dark incubations), mean water temperature inside chambers differed between day $1\left(23^{\circ} \mathrm{C}\right)$ and $2\left(19^{\circ} \mathrm{C}\right)$, which could have impacted solute fluxes.

Sediment cores were collected from within each plot to characterise sediment properties. Six small cores $(2.6 \mathrm{~cm}$ diameter $\times 2 \mathrm{~cm}$ depth) were pooled per plot and stored frozen, in the dark for analysis of sediment grain size and indicators of MPB biomass (chlorophyll $a(\mathrm{Chl} a)$ and phaeopigments (phaeo)). Four medium cores $(5 \mathrm{~cm}$ diameter $\times 7 \mathrm{~cm}$ depth) were collected and $0-2 \mathrm{~cm}$ and $2-5 \mathrm{~cm}$ sections were pooled for OC analysis at both depth intervals and $\mathrm{CaCO}_{3}$ content at $2-5 \mathrm{~cm}$ (depth of burial). Two large cores $(13 \mathrm{~cm}$ diameter $\times 15 \mathrm{~cm} \mathrm{depth})$ for macrofaunal analysis were collected and sieved in situ over a $500 \mu \mathrm{m}$ mesh, preserved in $70 \%$ isopropyl alcohol. Finally, porewater $\mathrm{pH}$ was measured in each plot using a digital field probe (Eutech $\mathrm{pHTestr1,2}$; accurate to $\pm 0.2 \mathrm{pH}$ units with a tip diameter of $3 \mathrm{~mm}$ ) at $\sim 2 \mathrm{~cm}$ depth following calibration using $\mathrm{pH} 4$ and 7 standard solutions.

Sediment samples were thawed, homogenised and divided for analysis of sediment properties. Grain size samples $(\sim 10 \mathrm{~g})$ were digested in $10 \%$ hydrogen peroxide to remove organic matter before measuring using a Malvern Mastersizer 2000 (particle size range 0.05-2000 $\mu \mathrm{m}$ ). Sediment pigment samples (Chl $a$ and phaeo) were processed using standard procedures ${ }^{83}$ and analysed on a Turner 10-AU fluorometer using an acidification step. Percent organic and $\mathrm{CaCO}_{3}$ contents were determined from $5 \mathrm{~g}$ dried sediment samples $\left(100^{\circ} \mathrm{C}\right.$ until constant weight) according to standard loss on ignition (LOI) procedures for $\mathrm{OC}^{84}$ and $\mathrm{CaCO}_{3}{ }^{85}$. Macrofauna samples were stained with Rose of Bengal and identified to lowest possible taxonomic level (usually species). Filtered water samples were thawed and analysed for dissolved inorganic nutrient species (ammonium $\left(\mathrm{NH}_{4}^{+}\right)$, nitrite $\left(\mathrm{NO}_{2}^{-}\right)$ and nitrate $\left(\mathrm{NO}_{3}^{-}\right)$) using standard colorimetric and fluorometric techniques (Astoria 2 Pacific autoanalyser).

Dissolved oxygen and nutrient fluxes $\left(\mu \mathrm{mol} \mathrm{m} \mathrm{m}^{-2} \mathrm{~h}^{-1}\right.$ ) were calculated by subtracting the final concentration ( $\mu \mathrm{mol} \mathrm{L} \mathrm{L}^{-1}$ ) of the given solute from the initial concentration and standardising by the incubation duration (h), chamber water volume (L) and enclosed sediment surface area $\left(\mathrm{m}^{-2}\right)$. These fluxes underpinned the quantification of key ecosystem functions: light chamber DO flux was equivalent to net PP (NPP) and dark chamber DO flux was equivalent to sediment oxygen consumption (SOC; a proxy for community metabolism), while fluxes of nitrogenous compounds indicated rates of nutrient cycling. Concentrations of $\mathrm{NO}_{2}{ }^{-}$and $\mathrm{NO}_{3}{ }^{-}$were frequently below detection limits and are thus combined and represented as $\mathrm{NO}_{\mathrm{x}}$.

In all analyses, organic matter treatment (i.e. the quantity of organic matter initially added to plots) was used as the continuous independent variable against which responses were measured. Using organic matter treatment better represented the initial stress experienced by the benthic ecosystem, whereas OC (measured at the time of flux incubations) alternatively indicated the degree of organic matter degradation that had occurred since plot establishment, which may vary according to the natural heterogeneity of the environment.

To determine whether organic matter and $\mathrm{CaCO}_{3}$ treatments (incorporated at $5 \mathrm{~cm}$ sediment depth) had altered sediment characteristics as intended, $\mathrm{OC}(2-5 \mathrm{~cm})$ and porewater $\mathrm{pH}$ were regressed against organic matter treatment, and a $t$-test was performed to detect differences in $\mathrm{CaCO}_{3}$ content $(2-5 \mathrm{~cm})$ between $+\mathrm{CaCO}_{3}$ and $-\mathrm{CaCO}_{3}$ plots. Simple linear regression identified significant $(\alpha<0.05)$ responses of the macrofauna community and ecosystem functions to organic matter treatment (using Statistica v13).

To simultaneously account for the gradient in organic matter treatment and assess the effects of $\mathrm{CaCO}_{3}$ addition on sediment characteristics, macrofauna community and ecosystem functions, PERMANOVA (using PERMANOVA+, Primer V7) were performed based on Euclidean distances with $\mathrm{CaCO}_{3}$ treatment considered a fixed factor and organic matter treatment a continuous co-variable. Where a significant interaction $(\mathrm{p}(\mathrm{perm})$ $<0.05$ ) occurred $-\mathrm{CaCO}_{3}$ and $+\mathrm{CaCO}_{3}$ treatments were considered separately for subsequent analyses, in the absence of a significant interaction the treatments were pooled. As PERMANOVA obtains p-values through permutation and does not assume normality, response variables were untransformed. For constructing DistLM, predictor variables were normalised and highly correlated variables (Pearson's $r>0.8$ ) were identified; the variable explaining the lesser proportion of variance was excluded from model selection to avoid collinearity ${ }^{86}$. Full models used a backward elimination procedure with the corrected Akaike's Information Criterion (AICc) and 9999 permutations to obtain the most parsimonious model ${ }^{87}$.

\section{Data Availability}

Upon acceptance of this manuscript, the data supporting the results will be archived in an appropriate public repository and the data DOI will be included at the end of the article. 


\section{References}

1. Mason, G. E. Poisoning And Acidification Of The Earth's Oceans. (Nova Science Publishers, Inc., 2010).

2. Wallace, R. B., Baumann, H., Grear, J. S., Aller, R. C. \& Gobler, C. J. Coastal ocean acidification: The other eutrophication problem. Estuar., Coast. Shelf S. 148, 1-13, https://doi.org/10.1016/j.ecss.2014.05.027 (2014).

3. Diaz, R. J. \& Rosenberg, R. Spreading dead zones and consequences for marine ecosystems. Science 321, 926-929, https://doi. org/10.1126/science.1156401 (2008).

4. Nixon, S. W. Coastal marine eutrophication: A definition, social causes, and future concerns. Ophelia 41, 199-219, https://doi.org/ 10.1080/00785236.1995.10422044 (1995).

5. Teichberg, M. et al. Eutrophication and macroalgal blooms in temperate and tropical coastal waters: nutrient enrichment experiments with Ulva spp. Global Change Biol. 16, 2624-2637, https://doi.org/10.1111/j.1365-2486.2009.02108.x (2010).

6. Körtzinger, A., Hedges, J. I. \& Quay, P. D. Redfield ratios revisited: Removing the biasing effect of anthropogenic $\mathrm{CO}_{2}$. Limnol. Oceanogr. 46, 964-970, https://doi.org/10.4319/lo.2001.46.4.0964 (2001).

7. Cai, W.-J. et al. Acidification of subsurface coastal waters enhanced by eutrophication. Nat. Geosci. 4, 766-770, https://doi. org/10.1038/ngeo1297 (2011).

8. Carstensen, J. \& Duarte, C. M. Drivers of pH variability in coastal ecosystems. Environ.Sci. Technol. 53, 4020-4029, https://doi. org/10.1021/acs.est.8b03655 (2019).

9. Wootton, J. T., Pfister, C. A. \& Forester, J. D. Dynamic patterns and ecological impacts of declining ocean pH in a high-resolution multi-year dataset. P. Natl. Acad. Sci. USA 105, 18848-18853, https://doi.org/10.1073/pnas.0810079105 (2008).

10. Duarte, C. et al. Is ocean acidification an open-ocean syndrome? Understanding anthropogenic impacts on seawater pH. Estuar. Coast. 36, 221-236, https://doi.org/10.1007/s12237-013-9594-3 (2013).

11. IPCC. Climate Change 2014: Synthesis Report. Contribution of Working Groups I, II and III to the Fifth Assessment Report of the Intergovernmental Panel on Climate Change. 151 (IPCC, Geneva, Switzerland, 2014).

12. Melzner, F. et al. Future ocean acidification will be amplified by hypoxia in coastal habitats. Mar. Biol. 160, 1875-1888, https://doi. org/10.1007/s00227-012-1954-1 (2013).

13. Sunda, W. G. \& Cai, W.-J. Eutrophication induced $\mathrm{CO}_{2}$-acidification of subsurface coastal waters: Interactive effects of temperature,

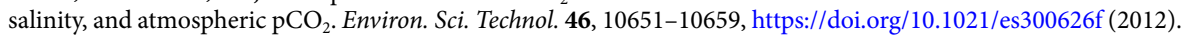

14. Provoost, P., van Heuven, S., Soetaert, K., Laane, R. \& Middelburg, J. Long-term record of pH in the Dutch coastal zone: a major role for eutrophication-induced changes. Biogeosci. Discuss. 7, https://doi.org/10.5194/bgd-7-4127-2010 (2010).

15. Fitch, J. E. \& Crowe, T. P. Combined effects of inorganic nutrients and organic enrichment on intertidal benthic macrofauna: an experimental approach. Mar. Ecol. Prog.Ser. 461, 59-70, https://doi.org/10.3354/meps09819 (2012).

16. Howarth, R. et al. Coupled biogeochemical cycles: eutrophication and hypoxia in temperate estuaries and coastal marine ecosystems. Front. Ecol. Environ. 9, 18-26, https://doi.org/10.1890/100008 (2011).

17. Pearson, T. H. \& Rosenberg, R. Macrobenthic succession in relation to organic enrichment and pollution of the marine environment. Oceanogr. Mar. Biol. Ann. Rev. 16, 229-311 (1978).

18. Ringwood, A. H. \& Keppler, C. J. Water quality variation and clam growth: Is pH really a non- issue in estuaries? Estuaries $\mathbf{2 5}$, 901-907, https://doi.org/10.1007/bf02691338 (2002).

19. Gazeau, F. et al. Impacts of ocean acidification on marine shelled molluscs. Mar. Biol. 160, 2207-2245, https://doi.org/10.1007/ s00227-013-2219-3 (2013).

20. Orr, J. C. et al. Anthropogenic ocean acidification over the twenty-first century and its impact on calcifying organisms. Nature 437, 681-686, https://doi.org/10.1038/nature04095 (2005).

21. Thomsen, J., Haynert, K., Wegner, K. M. \& Melzner, F. Impact of seawater carbonate chemistry on the calcification of marine bivalves. Biogeosciences 12, 4209-4220, https://doi.org/10.5194/bg-12-4209-2015 (2015).

22. Birchenough, S. N. R. et al. Climate change and marine benthos: A review of existing research and future directions in the North Atlantic. WIRES Clim. Change 6, 203-223, https://doi.org/10.1002/wcc.330 (2015).

23. Braeckman, U. et al. Role of macrofauna functional traits and density in biogeochemical fluxes and bioturbation. Mar. Ecol. Prog. Ser. 399, 173-186, https://doi.org/10.3354/meps08336 (2010).

24. Norling, K., Rosenberg, R., Hulth, S., Grémare, A. \& Bonsdorff, E. Importance of functional biodiversity and species-specific traits of benthic fauna for ecosystem functions in marine sediment. Mar. Ecol. Prog. Ser. 332, 11-23, https://doi.org/10.3354/meps332011 (2007).

25. Donohue, P. J. C. et al. Impact of exposure to elevated $\left.\mathrm{pCO}_{2}\right)$ on the physiology and behaviour of an important ecosystem engineer, the burrowing shrimp Upogebia deltaura. Aquat. Biol. 15, 73-86, https://doi.org/10.3354/ab00408 (2012).

26. Laverock, B. et al. Bioturbation determines the response of benthic ammonia-oxidizing microorganisms to ocean acidification. Philos. T. Roy. Soc. B. 368, 20120441, https://doi.org/10.1098/rstb.2012.0441 (2013).

27. Dahms, H.-U., Schizas, N. V., James, R. A., Wang, L. \& Hwang, J.-S. Marine hydrothermal vents as templates for global change scenarios. Hydrobiologia 818, 1-10, https://doi.org/10.1007/s10750-018-3598-8 (2018).

28. González-Delgado, S. \& Hernández, J. C. In Advances in Marine Biology Vol. 80 (Ed Charles Sheppard) 57-99 (Academic Press, 2018).

29. Hall-Spencer, J. M. et al. Volcanic carbon dioxide vents show ecosystem effects of ocean acidification. Nature 454, 96, https://doi. org/10.1038/nature07051 (2008).

30. Vizzini, S. et al. Trace element bias in the use of $\mathrm{CO}_{2}$ vents as analogues for low $\mathrm{pH}$ environments: Implications for contamination levels in acidified oceans. Estuar., Coast. Shelf S. 134, 19-30, https://doi.org/10.1016/j.ecss.2013.09.015 (2013).

31. Wahl, M., Saderne, V. \& Sawall, Y. How good are we at assessing the impact of ocean acidification in coastal systems? Limitations, omissions and strengths of commonly used experimental approaches with special emphasis on the neglected role of fluctuations. Mar. Freshwater Res. 67, 25-36, https://doi.org/10.1071/MF14154 (2015).

32. Günther, C.-P. Dispersal of intertidal invertebrates: A strategy to react to disturbance of different scales? Neth. J. Sea Res. 30, 45-56, https://doi.org/10.1016/0077-7579(92)90044-F (1992).

33. Greenfield, B. L., Kraan, C., Pilditch, C. A. \& Thrush, S. F. Mapping functional groups can provide insight into ecosystem functioning and potential resilience of intertidal sandflats. Mar. Ecol. Prog. Ser. 548, 1-10, https://doi.org/10.3354/meps11692 (2016).

34. Pilditch, C. A., Valanko, S., Norkko, J. \& Norkko, A. Post-settlement dispersal: The neglected link in maintenance of soft-sediment biodiversity. Biology Lett. 11, 20140795, https://doi.org/10.1098/rsbl.2014.0795 (2015).

35. Baggini, C., Issaris, Y., Salomidi, M. \& Hall-Spencer, J. Herbivore diversity improves benthic community resilience to ocean acidification. J. Exp. Mar. Biol. Ecol. 469, 98-104, https://doi.org/10.1016/j.jembe.2015.04.019 (2015).

36. Koch, M., Bowes, G., Ross, C. \& Zhang, X.-H. Climate change and ocean acidification effects on seagrasses and marine macroalgae. Glob. Change Biol. 19, 103-132, https://doi.org/10.1111/j.1365-2486.2012.02791.x (2013).

37. Vopel, K., Del-Río, C. \& Pilditch, C. A. Effects of CO2 enrichment on benthic primary production and inorganic nitrogen fluxes in two coastal sediments. Sci. Rep.-UK 8, 1035, https://doi.org/10.1038/s41598-017-19051-w (2018).

38. Widdicombe, S. et al. Impact of elevated levels of $\mathrm{CO}_{2}$ on animal mediated ecosystem function: The modification of sediment nutrient fluxes by burrowing urchins. Mar. Pollut. Bull. 73, 416-427, https://doi.org/10.1016/j.marpolbul.2012.11.008 (2013).

39. Hewitt, J. E., Thrush, S. F., Dayton, P. K. \& Bonsdorff, E. The effect of spatial and temporal heterogeneity on the design and analysis of empirical studies of scale-dependent systems. Am. Nat. 169, 398-408, https://doi.org/10.1086/510925 (2007). 
40. Lohrer, A. M., Thrush, S. F., Hewitt, J. E. \& Kraan, C. The up-scaling of ecosystem functions in a heterogeneous world. Sci. Rep.-UK 5, 10349, https://doi.org/10.1038/srep10349 (2015).

41. Snelgrove, P. V., Thrush, S. F., Wall, D. H. \& Norkko, A. Real-world biodiversity-ecosystem functioning: A seafloor perspective. Trends Ecol. Evol. 29, 398-405, https://doi.org/10.1016/j.tree.2014.05.002 (2014).

42. Gattuso, J. P., Frankignoulle, M. \& Wollast, R. Carbon and carbonate metabolism in coastal aquatic ecosystems. Annu. Rev. Ecol. Syst. 29, 405-434, https://doi.org/10.2307/221714 (1998).

43. Stumm, W. \& Morgan, J. J. Aquatic Chemistry: Chemical Equilibria And Rates in Natural Waters. Vol. 126 (John Wiley \& Sons, 2012).

44. Pickett, M. \& Andersson, A. Dissolution rates of biogenic carbonates in natural seawater at different $\mathrm{pCO}_{2}$ conditions: A laboratory study. Aquat. Geochem. 21, 459-485, https://doi.org/10.1007/s10498-015-9261-3 (2015).

45. Rao, A. M. F., Malkin, S. Y., Montserrat, F. \& Meysman, F. J. R. Alkalinity production in intertidal sands intensified by lugworm bioirrigation. Estuar. Coast. Shelf S. 148, 36-47, https://doi.org/10.1016/j.ecss.2014.06.006 (2014).

46. Clements, J. C. \& Chopin, T. Ocean acidification and marine aquaculture in North America: potential impacts and mitigation strategies. Rev. Aquacult. 9, 326-341, https://doi.org/10.1111/raq.12140 (2017).

47. Green, M. A., Waldbusser, G. G., Hubazc, L., Cathcart, E. \& Hall, J. Carbonate mineral saturation state as the recruitment cue for settling bivalves in marine muds. Estuar. Coast. 36, 18-27, https://doi.org/10.1007/s12237-012-9549-0 (2013).

48. Greiner, C. M., Klinger, T., Ruesink, J. L., Barber, J. S. \& Horwith, M. Habitat effects of macrophytes and shell on carbonate chemistry and juvenile clam recruitment, survival, and growth. J. Exp. Mar. Biol. Ecol. 509, 8-15, https://doi.org/10.1016/j.jembe.2018.08.006 (2018).

49. Rodil, I. F., Lohrer, A. M. \& Thrush, S. F. Sensitivity of heterogeneous marine benthic habitats to subtle stressors. PLoS ONE 8, 1-10, https://doi.org/10.1371/journal.pone.0081646 (2013).

50. Green, M. A., Waldbusser, G. G., Reilly, S. L., Emerson, K. \& O’Donnell, S. Death by dissolution: Sediment saturation state as a mortality factor for juvenile bivalves. Limnol. Oceanogr. 54, 1037-1047, https://doi.org/10.4319/lo.2009.54.4.1037 (2009).

51. Sulpis, O. et al. Current $\mathrm{CaCO}_{3}$ dissolution at the seafloor caused by anthropogenic $\mathrm{CO}_{2}$. Proc. Natl. Acad. Sci. USA 115, 11700-11705, https://doi.org/10.1073/pnas.1804250115 (2018).

52. Riera, R. et al. Effects of organic enrichment on macrofauna community structure: An experimental approach. Braz. J. Oceanogr. 61, 223-229, https://doi.org/10.1590/S1679-87592013000400003 (2013).

53. Sandwell, D. R., Pilditch, C. A. \& Lohrer, A. M. Density dependent effects of an infaunal suspension-feeding bivalve (Austrovenus stutchburyi) on sandflat nutrient fluxes and microphytobenthic productivity. J. Exp. Mar. Biol. Ecol. 373, 16-25, https://doi. org/10.1016/j.jembe.2009.02.015 (2009)

54. Thrush, S. F., Hewitt, J. E., Gibbs, M., Lundquist, C. \& Norkko, A. Functional role of large organisms in intertidal communities: Community effects and ecosystem function. Ecosystems 9, 1029-1040, https://doi.org/10.1007/s10021-005-0068-8 (2006).

55. Woodin, S. A. et al. Same pattern, different mechanism: Locking onto the role of key species in seafloor ecosystem process. Sci. Rep.UK 6, 26678, https://doi.org/10.1038/srep26678 (2016).

56. Celis-Plá, P. S. M. et al. Macroalgal responses to ocean acidification depend on nutrient and light levels. Front. Mar. Sci. 2, https:// doi.org/10.3389/fmars.2015.00026 (2015).

57. Johnson, V. R. et al. Responses of marine benthic microalgae to elevated $\mathrm{CO}_{2}$. Mar. Biol. 160, 1813-1824, https://doi.org/10.1007/ s00227-011-1840-2 (2013).

58. Lohrer, A. M., Thrush, S. F. \& Gibbs, M. M. Bioturbators enhance ecosystem function through complex biogeochemical interactions. Nature 431, 1092-1095, https://doi.org/10.1038/nature03042 (2004).

59. Solan, M. et al. Extinction and ecosystem function in the marine benthos. Science 306, 1177-1180, https://doi.org/10.1126/ science.1103960 (2004).

60. Braeckman, U. et al. Variable importance of macrofaunal functional biodiversity for biogeochemical cycling in temperate coastal sediments. Ecosystems 17, 720-737, https://doi.org/10.1007/s10021-014-9755-7 (2014).

61. Kitidis, V. et al. Impact of ocean acidification on benthic and water column ammonia oxidation. Geophys. Res. Lett. 38, https://doi. org/10.1029/2011gl049095 (2011).

62. Beman, J. M. et al. Global declines in oceanic nitrification rates as a consequence of ocean acidification. P. Natl. Acad. Sci. USA 108, 208-213, https://doi.org/10.1073/pnas.1011053108 (2011)

63. Suzuki, I., Dular, U. \& Kwok, S. C. Ammonia or ammonium ion as substrate for oxidation by Nitrosomonas europaea cells and extracts. J. Bacteriol. 120, 556-558 (1974).

64. Binnerup, S. J., Jensen, K., Revsbech, N. P., Jensen, M. H. \& Sørensen, J. Denitrification, dissimilatory reduction of nitrate to ammonium, and nitrification in a bioturbated estuarine sediment as measured with ${ }^{15} \mathrm{~N}$ and microsensor techniques. Appl. Environ. Microb. 58, 303-313 (1992).

65. Kessler, A. J., Roberts, K. L., Bissett, A. \& Cook, P. L. M. Biogeochemical controls on the relative importance of denitrification and dissimilatory nitrate reduction to ammonium in estuaries. Global Biogeochem. Cy. 32, 1045-1057, https://doi. org/10.1029/2018GB005908 (2018)

66. Cosby, B. J. et al. The nitrogen cascade. BioScience 53, 341-356, https://doi.org/10.1641/0006-3568(2003)053[0341:TNC]2.0.CO;2 (2003).

67. Seitzinger, S. P. \& Nixon, S. W. Eutrophication and the rate of denitrification and $\mathrm{N}_{2} \mathrm{O}$ production in coastal marine sediments. Limnol. Oceanogr. 30, 1332-1339, https://doi.org/10.4319/lo.1985.30.6.1332 (1985).

68. Hargrave, B. T. Similarity of oxygen uptake by benthic communities. Limnol. Oceanogr. 14, 801-805, https://doi.org/10.4319/ lo.1969.14.5.0801 (1969).

69. Bannister, R. J., Valdemarsen, T. Hansen, P. K. Holmer, M. \& Ervik, A. Changes in benthic sediment conditions under an Atlantic salmon farm at a deep, well-flushed coastal site. Aquac. Environ. Interact. 5, 29-47, https://doi.org/10.3354/aei00092 (2014).

70. Valdemarsen, T., Kristensen, E. \& Holmer, M. Sulfur, carbon, and nitrogen cycling in faunated marine sediments impacted by repeated organic enrichment. Mar. Ecol. Prog. Ser. 400, 37-53, https://doi.org/10.3354/meps08400 (2010).

71. Hargrave, B. T. et al. In The Interactions Between Sediments and Water 641-650 (Springer, 1997).

72. Kristensen, E. \& Kostka, J. E. In Interactions Between Macro- and Microorganisms in Marine Sediments 125-157 (American Geophysical Union, 2013)

73. Huettel, M. \& Gust, G. Solute release mechanisms from confined sediment cores in stirred benthic chambers and flume flows. Mar. Ecol. Prog. Ser. 82, 187-197 (1992).

74. Needham, H. R., Pilditch, C. A., Lohrer, A. M. \& Thrush, S. F. Context-specific bioturbation mediates changes to ecosystem functioning. Ecosystems 14, 1096-1109, https://doi.org/10.1007/s10021-011-9468-0 (2011).

75. Kennison, R. L. \& Fong, P. Extreme eutrophication in shallow estuaries and lagoons of California is driven by a unique combination of local watershed modifications that trump variability associated with wet and dry seasons. Estuar. Coast. 37, 164-179, https://doi. org/10.1007/s12237-013-9687-z (2014).

76. Quillien, N., Nordström, M. C., Le Bris, H., Bonsdorff, E. \& Grall, J. Green tides on inter- and subtidal sandy shores: Differential impacts on infauna and flatfish. J. Mar. Biol. Assoc. UK 98, 699-712, https://doi.org/10.1017/S0025315416002010 (2017).

77. de Winton, M. D., Hawes, I., Clayton, J. S., Champion, P. D. \& Smith, R. K. Sea lettuce dynamics and ecophysiology in Tauranga Harbour, Bay of Plenty. (Environment B.O.P., Tauranga District Council and Western Bay of Plenty District Council, NIWA Client Report BPR802, 1998). 
78. Eilers, P. H. C. \& Peeters, J. C. H. A model for the relationship between light intensity and the rate of photosynthesis in phytoplankton. Ecol. Model. 42, 199-215, https://doi.org/10.1016/0304-3800(88)90057-9 (1988).

79. Anthony, K. R. N., Ridd, P. V., Orpin, A. R., Larcombe, P. \& Lough, J. Temporal variation of light availability in coastal benthic habitats: Effects of clouds, turbidity, and tides. Limnol. Oceanogr. 49, 2201-2211, https://doi.org/10.4319/lo.2004.49.6.2201 (2004).

80. Drylie, T. P., Lohrer, A. M., Needham, H. R., Bulmer, R. H. \& Pilditch, C. A. Benthic primary production in emerged intertidal habitats provides resilience to high water column turbidity. J. Sea Res. 142, 101-112, https://doi.org/10.1016/j.seares.2018.09.015 (2018).

81. Lohrer, A. M., Cummings, V. J. \& Thrush, S. F. Altered sea ice thickness and permanence affects benthic ecosystem functioning in coastal antarctica. Ecosystems 16, 224-236, https://doi.org/10.1007/s10021-012-9610-7 (2013).

82. Thrush, S. F. et al. Changes in the location of biodiversity-ecosystem function hot spots across the seafloor landscape with increasing sediment nutrient loading. Proc. Roy. Soc. Ser. B-Bio. 284, https://doi.org/10.1098/rspb.2016.2861 (2017)

83. Arar, E. J. \& Collins, G. B. Method 445.0: In vitro determination of chlorophyll a and pheophytin a in marine and freshwater algae by fluorescence. (United States Environmental Protection Agency, Office of Research and Development, National Exposure Research Laboratory, 1997).

84. Heiri, O., Lotter, A. F. \& Lemcke, G. Loss on ignition as a method for estimating organic and carbonate content in sediments: reproducibility and comparability of results. J. Paleolimnol. 25, 101-110, https://doi.org/10.1023/A:1008119611481 (2001).

85. Wang, Q., Li, Y. \& Wang, Y. Optimizing the weight loss-on-ignition methodology to quantify organic and carbonate carbon of sediments from diverse sources. Environ. Monit. Assess. 174, 241-257, https://doi.org/10.1007/s10661-010-1454-z (2011).

86. Dormann, C. F. et al. Collinearity: a review of methods to deal with it and a simulation study evaluating their performance. Ecography 36, 27-46, https://doi.org/10.1111/j.1600-0587.2012.07348.x (2013).

87. Anderson, M., Gorley, R. N. \& Clarke, R. K. PERMANOVA+ for PRIMER: Guide to software and statistical methods (2008).

\section{Acknowledgements}

We sincerely thank the University of Waikato Benthic Ecology Team (D. Bell (technician), R. GladstoneGallagher, V. Rullens, S. Mangan, B. Monahan, G. Petersen, J. Cope and R. Koverman) for their assistance during field experiment setup and data collection, and R Gladstone-Gallagher and S. Hailes of NIWA for guidance during macrofauna species identification. Funding for TD's PhD scholarship and AML's time was provided by NIWA (Coasts and Oceans Research Programme 5, Managing Marine Ecosystems, COME1902). Field costs and CAP and AH's time were supported by MBIE contract UOWX1602.

\section{Author Contributions}

All authors contributed to designing the field experiment, T.P.D., H.R.N. and C.A.P. setup the experiment and collected field data, T.P.D. performed laboratory analyses and analysed data with assistance from C.A.P. \& A.M.L. T.P.D. wrote the first draft of the manuscript, and all authors contributed substantially to revisions.

\section{Additional Information}

Supplementary information accompanies this paper at https://doi.org/10.1038/s41598-019-48549-8.

Competing Interests: The authors declare no competing interests.

Publisher's note: Springer Nature remains neutral with regard to jurisdictional claims in published maps and institutional affiliations.

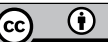

Open Access This article is licensed under a Creative Commons Attribution 4.0 International License, which permits use, sharing, adaptation, distribution and reproduction in any medium or format, as long as you give appropriate credit to the original author(s) and the source, provide a link to the Creative Commons license, and indicate if changes were made. The images or other third party material in this article are included in the article's Creative Commons license, unless indicated otherwise in a credit line to the material. If material is not included in the article's Creative Commons license and your intended use is not permitted by statutory regulation or exceeds the permitted use, you will need to obtain permission directly from the copyright holder. To view a copy of this license, visit http://creativecommons.org/licenses/by/4.0/.

(c) The Author(s) 2019 